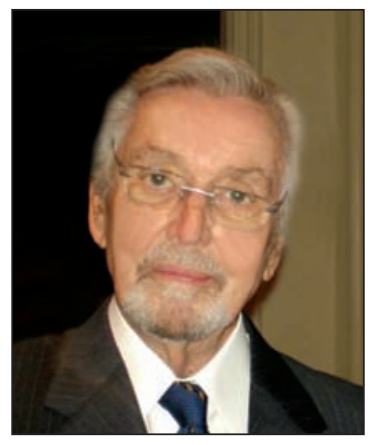

\title{
Em memória do Prof. Humberto de Castro Lima
}

\author{
$1924-2008$
}

Humberto de Castro Lima formouse, em 1948, pela Faculdade de Medicina da Bahia. No terceiro ano do curso seu interesse pela Oftalmologia foi despertado pela oportunidade de trabalhar com seu irmão e mestre Professor Orlando de Castro Lima, Otorrinolaringologista e Oftalmologista respeitado. Apesar de ter também grande atração pela Psiquiatria e pela Neurologia, tendo trabalhado com o Professor Rubim de Pinho, antes mesmo da conclusão de sua graduação fez um curso de especialização de três meses em Oftalmologia, ministrado pelo eminente professor Moacyr Álvaro. E, em seguida, estimulado por José Silveira, que na época era presidente da Associação Bahiana de Medicina, foi para os Estados Unidos, em agosto de 1949, permanecendo por lá durante quase 4 anos, como residente no Passaic General Hospital, em Nova Jersey e, depois, no New York Eye and Ear Infirmary, o mais antigo e tradicional hospital de olhos da América. Ao final, submeteu-se aos exames do American Board of Ophthalmology e recebeu convite para instalar-se definitivamente nos Estados Unidos. Mas seu desejo sempre havia sido aprender e voltar para casa, para sua querida Bahia, e servir a sua gente. E foi a partir dela que construiu sua reputação e ganhou credibilidade nacional e internacional. No retorno ao Brasil, em 1952, aproximou-se de um dos mais notáveis sanitaristas brasileiros, o professor Manoel Ferreira e, com sua ajuda, instalou em um barracão da Fundação Gonçalo Muniz, em Salvador, uma clínica para atendimento de pessoas carentes, embrião do que viria a ser o futuro Instituto Brasileiro de Oftalmologia e Prevenção da Cegueira (IBOPC), criado em 1959, hoje um dos maiores e mais respeitados serviços de oftalmologia do país, voltado para a assistência, pesquisa e ensino, oferecendo, anualmente, 18 vagas para médicos residentes. Ao lado dessas atividades assistenciais e de prevenção da saúde ocular, a vocação para o ensino levou-o a promover inúmeros cursos e tornar-se professor titular de Oftalmologia da Escola Bahiana de Medicina e Saúde Pública. Em 1965, doutorou-se pela Faculdade Nacional de Medicina da Universidade do Brasil e tornou-se Docente Livre de Oftalmologia pela mesma instituição. Durante toda vida foi membro ativo do Conselho Brasileiro de Oftalmologia, foi fundador da Sociedade Pan-Americana de Glaucoma, membro da Sociedade Pan-Americana de Oftalmologia, patrono da Associação Pan-Americana de Oftalmologia, membro do Instituto Barraquer, sócio benemérito da Sociedade Italiana de Oftalmologia e membro titular da Acade- mia de Medicina da Bahia, entre outras atividades associativas. Foi observador, professor convidado e conferencista em inúmeras instituições e eventos internacionais. Presidiu encontros e congressos nacionais. Orador brilhante, grande amante da filosofia e da literatura, teve sempre sua arte requisitada para ser orador oficial nos mais diversos eventos e fez, também, a alegria de seus amigos, de seus 3 filhos e dos companheiros nas rodas de conversa informais. Todos aqueles que privaram de sua companhia, inclusive no trabalho, como os funcionários das instituições que dirigiu, beneficiaram-se de sua personalidade forte, às vezes intempestiva, mas profundamente amorosa e solidária, sempre disposta a ensinar e ajudar. Recebeu inúmeras honrarias, entre elas a Medalha Tomé de Souza e a Medalha de Ouro da Universitá degli Studi di Roma. Foi Diretor-executivo do IBOPC e Coordenador Geral da Fundação Bahiana para Desenvolvimento das Ciências, mantenedora da Escola Bahiana de Medicina e Saúde Pública, a partir de 1992, tendo também imprimido nela sua marca de grande realizador, criando dois novos campi, ampliando muito a capacidade assistencial da instituição e aumentando o número de cursos oferecidos, com foco principal na qualidade dos mesmos para formar profissionais e cidadãos altamente qualificados e capazes de atender às necessidades da população. Por sua visão de futuro, criou, também, um mestrado e um doutorado em Medicina e Saúde Humana e um mestrado em Oftalmologia, tornando a Escola Bahiana de Medicina uma das raras instituições do Norte e do Nordeste a oferecer pós-graduação stricto-sensu nesta área. Foi um homem com espírito público, em luta permanente para conseguir dar atendimento digno à população carente da Bahia. Foi um grande mestre, com um enorme prazer de ensinar. Foi um grande médico, como poucos, capaz de estabelecer uma relação médico-paciente impecável, feita de conhecimento, técnica, respeito e amor verdadeiro pelo homem que sofre e que busca alívio para suas dores, relação na qual o dinheiro, a retribuição financeira nunca importou. Foi um grande empreendedor, pois nunca deixou de inventar um projeto novo com o qual entusiasmar seus parceiros, seus amigos, seus colaboradores. Foi um grande homem, que aos 80 anos sonhou tanto quanto aos 20 e nos deixou um legado e um exemplo de capacidade de luta, de resistência e de realização.

O Prof. Humberto de Castro Lima nasceu em 03 de outubro de 1924 e faleceu em 01 de julho de 2008.

Escrito pela viúva Dra. Maria Luisa Carvalho Soliani 